\title{
The 21st-Century Teacher: Teacher's Competence Within the Character Education Framework Towards A Cultural-Oriented Development and Promoting Tolerance
}

\author{
Sudirman $^{1}$ \\ ${ }^{1}$ State University of Gorontalo, Gorontalo, Indonesia \\ Correspondence: Sudirman, State University of Gorontalo, Gorontalo, Indonesia.
}

Received: March 12, 2019

Accepted: April 25, 2019

Online Published: July 29, 2019

doi:10.5539/ies.v12n8p21

URL: https://doi.org/10.5539/ies.v12n8p21

\begin{abstract}
Teachers play a major role in the cultural-oriented and tolerant development character education considering the fact that teachers interact with students the most. This paper investigates the role of certified teachers in character education in promoting cultural-oriented development and tolerance. The results reveal that the competence of the certified teachers positively contributes to the character education in conceptualizing the values above. In providing in-depth insight regarding the contribution of the 21st-century teachers, it is concluded that the certified teachers have attempted to promote character values to the students to conceptualize a cultural-oriented development and promoting tolerance.
\end{abstract}

Keywords: competence, character, cultural-oriented, tolerant

\section{Introduction}

Competence is a term describing a particular skill or capability of an individual in his or her profession, such as a teacher. A teacher is among the components in education whose role is to produce quality students and to promote cultural understanding and tolerance in a multicultural society. In attempts to teach character education to the students in aspects, such as cognitive, affective and psychomotor, a teacher is demanded to possess four competencies. This is also because the quality of the students is determined by the teacher's competence in transferring the knowledge, especially to shape students' character and attitude.

The government has endeavored to produce quality teachers in terms of all aspects, i.e., academic/pedagogic, professional, and social through workshops and training. This is aimed at promoting understanding and tolerance in a multicultural society in Indonesia by which it equips the students with in-depth insight to deal with the issues of intolerance. It is also expected that today's teachers are able to focus on addressing such issues to conceptualize a cultural-oriented development and promoting tolerance.

Students, as one of the elements in education, without question expect significant electoral effects. Furthermore, it is crucial for students to respond to various challenges in a society with diverse culture, religion, races and groups. It is essential for $21^{\text {st- }}$ century teachers to improve their competence to conceptualize a peaceful society, where mutual understanding spread across its people in the dynamics of a multicultural setting.

\subsection{Research Question}

1) How is the contribution of a teacher's competence in improving student character education?

2) How is the role of a teacher's competence in promoting a cultural, tolerant society in a multicultural setting?

\subsection{Research Objective}

The objectives of this present study are:

1) To provide information regarding the correlation of teacher's competence in developing student character education to the society and teachers.

2) To explore the role of a teacher's competence in promoting a cultural-based and tolerant society in a multicultural setting.

3) To provide a reference for teachers and policymakers in enhancing teacher's competence to develop character 
education for students and to conceptualize a cultural-based and tolerant society in a multicultural setting.

\section{Research Methodology}

This qualitative research employed several methods in collecting both primary and secondary data. The primary data were generated from observation, in-depth interview, and documentation while the secondary data were from several literatures relevant to this present study. Processes of data analysis comprised data reduction, data display, and summing up a conclusion. The informant of this study involved teachers, a school principal, students, and supervisors.

\section{Discussion}

\subsection{Teacher's Competence}

Teacher's competence refers to a quality that a teacher must possess to identify the student's characteristic as a whole. The competence is divided into four, i.e., pedagogical, professional, individual and social competence. Each competency is unique from one to another. The quality of teacher's competence depends on the situation where the teacher interacts with a particular environment. This is in line with Symanyuk and Pecherkina (2016) that a specific situation of education atmosphere contributes to the competence of a teacher. A great deal of innovation affects the level of the competence of a teacher, regardless of his or her level of prosperity.

Teacher's competence is not an independent component; it is supported by some factors. Symanyuk and Pecherkina (2016) further points out that the teaching experience in innovative schools influences the interest of the teacher. This shapes the perception of a teacher in aiming for success by which it builds emotional wellbeing and the ability to live independently.

In addition to external factors, internal factors also play a major role in teacher's competence. This refers to the awareness in preparing everything that a teacher needs to deal with complexity in his or her life. This aspect, interestingly, was not in the list of priority of the teacher. However, the rapid growth of technology in all aspects including education has changed the teacher's paradigm of character education. This is because social interaction is affected by the character of an individual and the fact that the development of technology and globalization provides media for individuals in interacting with people from different background and culture. In the last two decades, Altbach (2005), Friedman (2006), Johnson, Lenartowicz, and Apud (2006), and Mok (2006) find out that the significant development of technology and globalization has drastically changed some aspects of life, e.g., business, communication, and education.

A teacher is not only responsible for transferring knowledge to their students, but also promoting the character value. The responsibility of teachers refers to three indicators of assessment, i.e., knowledge, attitude, and skills.

In preparing the students to excel in the academic setting (as a result of the pedagogical competence of a teacher), a teacher is urged to design engaging learning for students since this drives the students' motivation in learning. A teacher is also urged to teach character education for the students. This is considered as a result of the individual and social competence of the teacher in interacting with others in a multicultural setting. Such behaviors modeled by the teacher allow the students to practice tolerance.

The aforementioned competencies ensure that the knowledge transfer is of valid as it functions as a model for the students in enhancing their intellectual and emotional quotient. With that being said, developing multi-skills is essential for a teacher to cope with various backgrounds of the students. Chen (2015) points out that multi-skills help the teacher to interact with such students and adapt to a particular environment. Lister's (1999) further adds some perspectives relating to cultural awareness, knowledge, understanding, cognitive sensitivity, emotion and attitude. This also resonates to the opinion by Steinaker and Bell's (1979) regarding the taxonomy of experience. This term asserts that one's experience determines his or her competence. This implies that experience and condition of an environment enhance the teacher's competence by which it helps the implementation of character education.

All in all, the competence of a certified teacher is central to character education for the students as it helps them to interact with each other in a multi-cultural setting and to promote tolerance among them.

\subsection{Character}

The term "character" refers to the attitude of a person in which it determines the behavior of the individual. According to Gray (2010), "character" is a term describing understanding, care, and behavior based on ethical values, e.g., respect, responsibility, honesty, fairness and care. There have been some issues around society nowadays; this is especially about problems around the students' life. Gray (2010) claims that the crisis of character is spreading across the society, particularly the teenagers. The teenagers are prone to some issues of work 
ethics, narcotics problem, sexual harassment, violence, robbery, and others. With that being said, implementing character education is a necessity for teachers since students are the future generation that is going to replace the teacher. Providing good role models is able to help the students as they are going to adopt everything that the teacher taught by which it contributes to the students' life in society.

Kirschenbaum (1995, p. 28) emphasizes the importance of education in the growth and development of the students. Kirschenbaum points out that the development of the students involves the awareness, affection, self-control, and humble attitude. As a result, character education plays a major role in living in a multicultural society to promote tolerance. Kamaruddin (2012) further explains that character education is an effort to shape a basis for a meaningful and productive society, enabling its people to behave and act fairly in accordance to the norm and morale.

A research by Davidson, Lickona, and Khmelkov (2007) reveals that character education contributes to academic and non-academic (extra-curricular activities) achievement of the students. This also resonates to the result seen in Smith et al. (2003, pp. 19-31) that character education improves the students' achievement. In other words, a competent teacher, considering the interaction with his or her students, is demanded to apply comprehensive approaches in shaping the students' character through character education. This notion emphasizes the essence of the teacher's competence as the term refers to an individual's capability relating to his or her job.

In conclusion, character education is central to improving the quality of human resources. A teacher plays a major role in conceptualizing such a goal by producing quality students in an academic and non-academic setting. Therefore, a teacher is urged to be competent to employ specific approaches to promote cultural-oriented development and tolerance as these components are essential in a multicultural society.

\subsection{Culture}

The term culture refers to one's behavior. Indonesia is a diverse country with various cultures. This has an impact on the development of science because of the dynamics of life in the midst of society. In other words, the development of science requires cultural adjustment as a reference. According to Chen (2015), a multicultural aspect is important in cultural adjustment; this is reflected in the way a person learns from mistakes or things related to the ability to learn new things. Black (1990) further explains that intercultural competence contributes to someone's career.

Considering the different socio-cultural background of the students, educators with an understanding of multicultural and ability to interact are needed. It aims to provide an understanding of the meaning of togetherness amid cultural differences. Malakolunthu, Siraj, and Rengasamy (2010) mentioned three levels of "multiculturalism" typology, namely: (1) The product, explaining the culture, concept, idea, principle and different group practices; (2) Confluent relation between product and process. This notion provides the teacher a medium to not only address the question "what" of the concept of culture, ideas, principles, and practices but also to respond to other components, such as "why," "when," and "how." (3). Process and philosophical orientation; a teacher is expected to define the concepts, ideas, principles, and practices of the culture. This is to gain the awareness that people have different perspective and ones are urged to respect to such a difference.

\subsection{Tolerance}

Tolerance is an act of mutual respect for differences. This is very necessary for the life of a pluralistic society. Such a notion can be conceptualized by preparing students to identify the concept of moral and responsibility about tolerance. Colesante and Biggs (1999) points out that this not about teaching tolerance to society. Considering that tolerance is more principled in their moral judgment (Biggs \& Barnett, 1981; Rest, 1988), education has a role in encouraging the conceptualization of an understanding, principle, and attitude among groups. Colesante and Biggs (1999) argue that education encourages attitudes among positive groups to understand a difference in beliefs.

Schools as educational institutions can take part in teaching the dynamics of pluralistic community life to students. The aim is to promote acceptance regarding each other's differences for the students and provide an understanding of controversial issues regarding pluralistic societies. A teacher's competence is central to such a process. Colesante and Biggs (1999) mentions two methods of teaching tolerance, i.e., propositional and narrative thinking. Propositional thinking provides a logical argument that illustrates a valid, generalized truth, while narrative thinking explains a more concrete explanation to comprehend some phenomena.

In conclusion, education promotes tolerance for students in dealing with the dynamics of multicultural society and the development of technology in a globalized world. A teacher takes part in achieving such a target and to move towards a cultural-oriented development and promoting tolerance. 


\section{Conclusion}

Certified teacher's competence in the 21 st century positively contributes to society and particularly students in a pluralistic society. The teacher plays a role in promoting character education. This helps the students to respect the difference among the people. This is to conceptualize a cultural-oriented development and promoting tolerance.

\section{References}

Altbach, P. G. (2005). Globalization and the university: Myths and realities in an unequal world. In National Education Association (Ed.), The NEA 2005 almanac of higher education (pp. 63-74). Washington, DC: National Education Association.

Benninga, J. S., Berkowitz, M. W., Kuehn, P., \& Smith, K. (2003). The relationship of character education implementation and academic achievement in elementary schools. Journal of research in character education, 1(1), 19-32.

Biggs, D. A., \& Barnett, R. (1981). Moral judgement development of college students. Research in Higher Education, 14(2), 91-102. https://doi.org/10.1007/bf00976287

Black, J. S. (1990). The relationship of personal characteristics with the adjustment of Japanese expatriate managers. Management International Review, 30(2), 119-134.

Chen, Y. L. (2015). Examining factors in cross-cultural competence development in Taiwan college students. The Asia-Pacific Education Researcher, 24(2), 329-340. https://doi.org/10.1007/s40299-014-0183-4

Colesante, R. J., \& Biggs, D. A. (1999). Teaching about Tolerance with Stories and Arguments. Journal of Moral Education, 28(2), 185-199. https://doi.org/10.1080/030572499103205

Davidson, M., Lickona, T., \& Khmelkov, V. (2007). Smart and Good Schools: A Paradigm Shift for character Education. Education Week, 27(12), 31-40. https://doi.org/10.4324/9780203114896.ch17

Friedman, T. L. (2006). The world is flat: A brief history of the twenty-first century. New York, NY: Farrar, Straus and Giroux.

Gray, T. (2010). Character education in schools. ESSAI, 7(1), 21. Retrieved from http://dc.cod.edu/essai/vol7/iss $1 / 2$

Johnson, J. P., Lenartowicz, T., \& Apud, S. (2006). Cross-cultural competence in international business: Toward a definition and a model. Journal of International Business Studies, 37(4), 525-543. https://doi.org/10.1057/palgrave.jibs.8400205

Kamaruddin, S. A. (2012). Character Education and Students Social Behavior. Journal of Education and Learning, 6(4), 223-230.

Kirschenbaum, H. (1995). 100 Ways to Enhance Values and Morality in Schools and Youth Settings. Massachusetts: Allyn \& Bacon.

Lister, P. (1999). Ataxonomy for developing cultural competence. Nurse Education Today, 19(4), 313-318. https://doi.org/10.1054/nedt.1999.0642

Malakolunthu, S., Siraj, S., \& Rengasamy, N. C. (2010). Multicultural Education as a Reform Initiative: Reconstructing Teacher Preparation for Malaysian "Vision Schools". The Asia-Pacific Education Researcher, 19(3), 453-464. https://doi.org/10.3860/taper.v19i3.1853

Mok, K. H. (2006). Education reform and education policy in East Asia (pp. 483-485). New York, NY: Routledge.

Rest, J. R. (1988). Why does college promote moral judgement? Journal of Moral Education, 17, 183-194. https://doi.org/10.1080/0305724880170303

Spreitzer, G. M., McCall, M. W., \& Mahoney, J. D. (1997). Early identification of international executive potential. Journal of Applied Psychology, 82(1), 6-29. https://doi.org/10.1037/0021-9010.82.1.6

Steinaker, N., \& Bell, M. R. (1979). The experiential taxonomy: A new approach to teaching and learning. London: Academic Press.

Symanyuk, E. E., \& Pecherkina, A. A. (2016). A study on the components of teachers' professional competence. New Educational Review, 44(2), 198-210. 


\section{Copyrights}

Copyright for this article is retained by the author(s), with first publication rights granted to the journal.

This is an open-access article distributed under the terms and conditions of the Creative Commons Attribution license (http://creativecommons.org/licenses/by/4.0/). 